\title{
Primary bladder amyloidosis
}

\author{
Michael Wilkinson, Deirdre Mary Fanning, Hugh Flood
}

Urology Department, Midwestern Regional Hospital, Limerick, Ireland

Correspondence to Miss Deirdre Mary Fanning, fanningdee@yahoo.co.uk

\section{Summary}

Primary localised bladder amyloidosis is a very rare entity, with only 200 cases reported worldwide. Our case illustrates the classical presentation of isolated bladder amyloidosis with frank painless haematuria and irritative voiding symptoms.

\section{BACKGROUND}

Primary bladder amyloidosis assumes clinical importance as it clinically masquerades as a malignancy as in the case presented. Isolated bladder amyloidosis is most frequent in the fifth and sixth decade. It has equal sex preponderance. Histological diagnosis is essential. Recurrence rates postresection is estimated at $50 \%$.

\section{CASE PRESENTATION}

A 69-year-old lady was referred to the urology outpatient with an 18-month history of intermittent frank painless haematuria. There was no associated lower urinary tract or constitutional symptoms. Medical history was positive for hypertension, hypercholesterolemia and gastro-oesophageal reflux disease. Her regular medications included aspirin, atacand, lipostat and omeprazole. She had no known drug allergies. Surgical history included appendicectomy, hysterectomy, oophorectomy and cystocoele repair. There was no significant family history. She was a non-smoker. Clinical examination revealed no significant abnormality.

\section{INVESTIGATIONS}

Serum renal, liver and bone profiles were within normal ranges. Urine cytology was unremarkable. Urine and serum electrophoresis results were normal, with a $\kappa / \lambda$ ratio of 0.827 (0.260-1.650). Renal ultrasound and skeletal survey were unremarkable. CT of the abdomen and pelvis
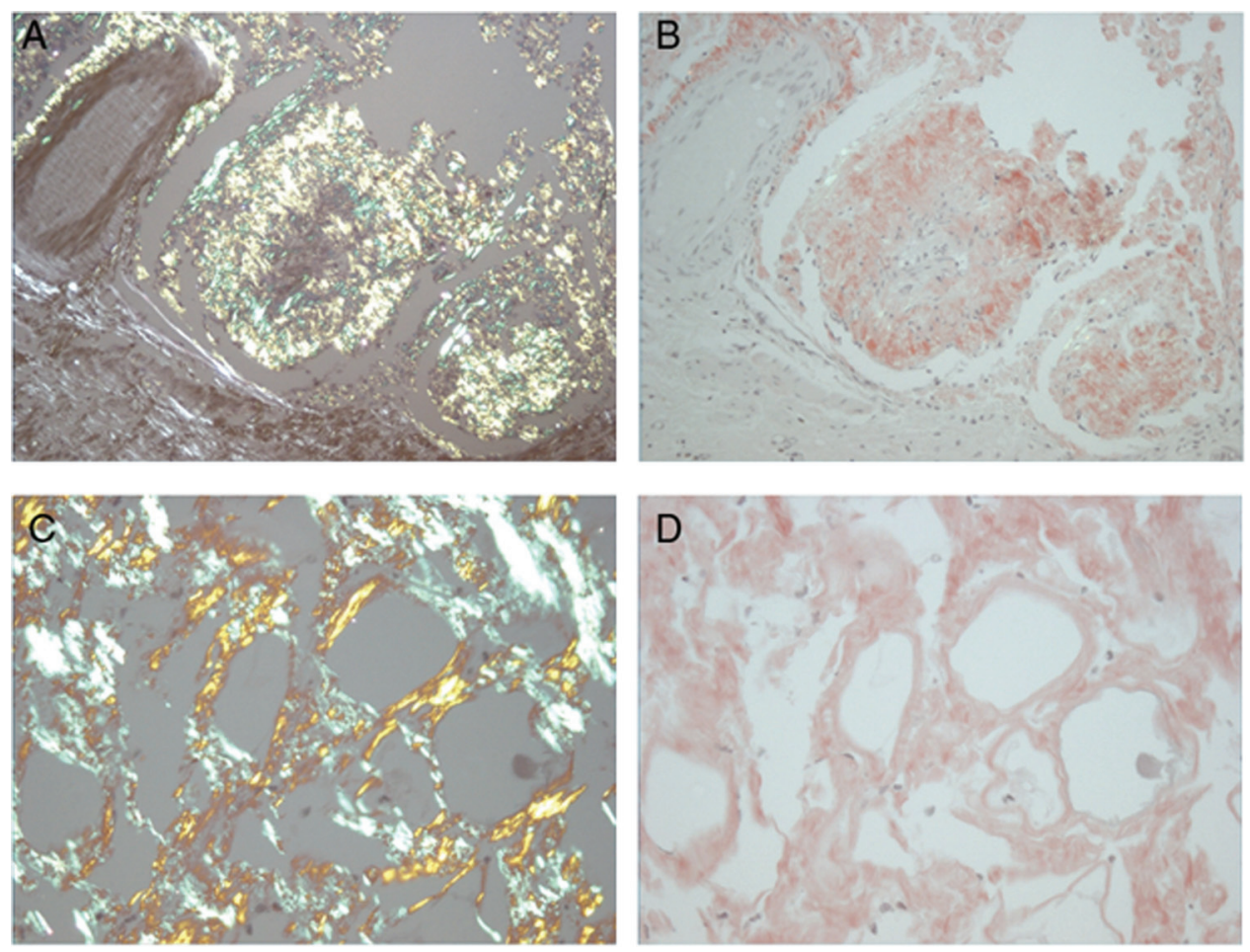

Figure 1 (A) Congo red without apple green birefringence at $\times 10$ objectives. (B) Congo red with apple green birefringence at $\times 10$ objectives. (C) Congo red without apple green birefringence at $\times 20$ objectives. (D) Congo red with apple green birefringence at $\times 20$ objectives. 
showed an unusual appearance of the urinary bladder with markedly enlarged pelvic veins. There was no associated perivesical lymphadenopathy. Cystoscopy revealed a haemorrhagic oedematous patch on the left lateral sidewall of the bladder.

\section{DIFFERENTIAL DIAGNOSIS}

Neoplasia, lymphoma and haemorrhagic cystitis were among the differentials.

\section{TREATMENT}

A transurethral resection was performed. Pathology showed no evidence of cancer. Staining with alkaline Congo red revealed a salmon pink appearance. Apple green birefringence was detected under polarised light (figure 1). No staining was identified at immunohistochemistry using monospecific antibodies reactive with serum amyloid A protein ,transthyretin , apolipoprotein A1 or, with $\mathrm{\kappa}$ - and $\lambda$-immunoglobulin light chains. The amyloid did not stain with any of these antibodies.

\section{OUTCOME AND FOLLOW-UP}

She was diagnosed with primary amyloidosis of the bladder. Her haematuria resolved. She shall be followed by yearly surveillance cystoscopy.

\section{DISCUSSION}

Amyloidosis is characterised by the extracellular deposition of proteins. Amyloidosis may be primary or secondary depending on whether it is due to underlying immune dyscrasia or secondary to a chronic inflammatory disorder. While systemic amyloid can occur anywhere in the urinary tract, including the kidney, renal pelvis, ureter, urethra or corpora, primary localised bladder amyloidosis is a rare urological disease with approximately 200 cases reported in the literature. ${ }^{1-3}$

Chronic cystitis and inflammation lead to the synthesis and accumulation of miss folded amyloid precursor protein, particularly light chain immunoglobulin protein. ${ }^{4}$ Bladder amyloidosis affects males and females equally in about the fifth and sixth decades of life. The classical presentation with primary bladder amyloidosis is gross painless haematuria (60\%), irritative voiding symptoms (20\%) or both $(20 \%) .^{1-3}$ Primary bladder amyloidosis assumes clinical importance as it clinically masquerades as a malignancy as in the case presented.

The cystoscopic appearance can often puzzle the clinician with carcinoma and interstitial cystitis the competing differentials in most cases. Deposits vary from multiple yellow plaques to multiple ulcerated polypoid masses to diffuse irregular thickening of the bladder wall. It is for this reason that histological evaluation is essential for diagnosis. Histologically, as in our case, the diagnosis is confirmed by the presence of fluorescent apple green birefringence after Congo red staining and visualisation of the specimen under polarised light. The composition of the amyloid can be demonstrated immunohistochemically. AL and AA amyloid deposits can be distinguished to some extent histochemically by treating with potassium permanganate $\left(\mathrm{KMNO}_{4}\right)$.

Typically primary amyloidosis deposits superficially beneath the surface mucosa sometimes extending into the superficial smooth muscle of the urinary bladder. In secondary amyloidosis, the amyloid tends to accumulate in the bladder vasculature thus explaining why secondary amyloidosis with diffuse bladder involvement has a high mortality of $30 \%$ with its potential for massive haemorrhage. ${ }^{5}$

As demonstrated in our case, transurethral resection is the treatment of choice with primary bladder amyloidosis. Medical treatments such as intravesical dimethyl sulfoxide installation and oral colchicines have also been tried with limited success.

Recurrence rates postresection is estimated to be around $50 \%{ }^{6}$ Recurrence warrants full reassessment as cases of coexistent malignancy have been reported. ${ }^{4}$ While no official guidelines exist for surveillance, most centers would advocate follow-up cystoscopy at 1-3 year intervals.

\section{Learning points}

- Amyloidosis is characterised by the extracellular deposition of proteins. Amyloidosis is a heterogenous group of disorders which may affect single or multiple organ systems. It may represent a generalised or localised disease process.

- Isolated bladder amyloidosis classically presents with painless frank haematuria and irritative voiding symptoms.

- Recurrence rates postresection is estimated to be around $50 \%$.

\section{Competing interests None.}

Patient consent Obtained.

\section{REFERENCES}

1. Malek RS, Wahner-Roedler DL, Gertz MA, et al. Primary localized amyloidosis of the bladder: experience with dimethyl sulfoxide therapy. J Urol 2002;168:1018-20

2. Caldamone AA, Elbadawi A, Moshtagi A, et al. Primary localized amyloidosis of urinary bladder. Urology 1980;15:174-80.

3. Biewend ML, Menke DM, Calamia KT. The spectrum of localized amyloidosis: a case series of 20 patients and review of the literature. Amyloid 2006;13:135-42.

4. Khan SM, Birch PJ, Bass PS, et al. Localized amyloidosis of the lower genitourinary tract: a clinicopathological and immunohistochemical study of nine cases. Histopathology 1992;21:143-7.

5. Tirzaman 0, Wahner-Roedler DL, Malek RS, et al. Primary localized amyloidosis of the urinary bladder: a case series of 31 patients. Mayo Clin Proc 2000; 75:1264-8.

6. Ferch R, Haskell R, Farebrother T. Primary amyloidosis of the urinary bladder and ureters. Br J Urol 1997;80:953-4. 


\section{BMJ Case Reports}

This pdf has been created automatically from the final edited text and images.

Copyright 2011 BMJ Publishing Group. All rights reserved. For permission to reuse any of this content visit http://group.bmj.com/group/rights-licensing/permissions.

BMJ Case Report Fellows may re-use this article for personal use and teaching without any further permission.

Please cite this article as follows (you will need to access the article online to obtain the date of publication).

Wikinson M, Fanning DM, Flood H. Primary bladder amyloidosis. BMJ Case Reports 2011;10.1136/bcr.05.2011.4211, date of publication

Become a Fellow of BMJ Case Reports today and you can:

- Submit as many cases as you like

- Enjoy fast sympathetic peer review and rapid publication of accepted articles

- Access all the published articles

- Re-use any of the published material for personal use and teaching without further permission

For information on Institutional Fellowships contact consortiasales@bmjgroup.com

Visit casereports.bmj.com for more articles like this and to become a Fellow 